DOI: 10.22616/REEP.2019.009

\title{
Pedagogical Training in the Preparation of Prospective Teachers of Professional Economic Subjects
}

\author{
Katarina Krpalkova-Krelova ${ }^{1}$ Dipl. Ing., PhD.; Pavel Krpalek ${ }^{2}$ Dipl. Ing., Ph.D. \\ University of Economics in Prague, Czech Republic \\ katarina.krelova@vse.cz'; krpp01@vse.cz²
}

\begin{abstract}
The paper deals with the pedagogical training the researchers consider to be necessary in the undergraduate preparation of prospective teachers. It has its irreplaceable place in the curriculum of universities which have been preparing prospective teachers of vocational subjects. The undergraduate teachers' education consists of four components: general background, pedagogical-psychological component, subject-matter and pedagogical training. There is a trend in all faculties educating prospective teachers that the subject-matter is far more important than the other three components. The researchers present the concept of qualitative and quantitative research. The aim of the qualitative research was to identify the weaknesses of the prospective teachers' performance. The research method of moderated discussion was used and 32 prospective teachers from the faculty schools were the respondents. The researchers found that the most common problems for the prospective teachers when teaching were to manage class discipline, to have the ability to motivate students, and the lack of adequacy of the topic when lecturing. The aim of quantitative research was to determine the quality of the pedagogical training at the faculty training schools. To meet the research aim three research hypotheses were set. Forty - seven students of the master's study programme Teaching of Economic Subjects at the University of Economics in Prague took part in the research. Through the form of the questionnaire survey, students' attitudes were assessed on various evaluated aspects of pedagogical training. The course of pedagogical training was evaluated by students positively (1.80); the material equipment of training schools (2.51) and the time range of pedagogical training (2.06) were assessed as a weaker side. The research hypotheses were confirmed. On the basis of the results of the research, the researchers propose possible measures to improve pedagogical training. The researchers are of the opinion that it is appropriate to include various forms of training in the preparation of prospective teachers to bring theory into line with training, but it is important to remember that no simulations will replace the direct experience in real situations, in training schools.
\end{abstract}

Keywords: university education, pedagogical training, prospective teacher, pedagogical competencies, self-reflection.

\section{Introduction}

The pedagogical training participates in the quality of performing the teaching profession. Pedagogical training during tertiary education cannot be understood only as a training itself, its content, organization, methods and management, but also as a relationship between theory and training in prospective teachers' education. Such an approach is important not only for the design of training in the system of working with prospective teachers, but also for the whole concept of working with prospective teachers. Therefore, students are required to master not only the basic principles of the chosen field of study but also the pedagogical-psychological ones to build the system of activities in relation to the content of the studied fields and to be able to theoretically synthesize theories, which have already proved to be efficient, and experience in real teaching situations (Kozina, Erjavsek, Kostanjevec, 2015). Applying academic knowledge, competencies, skills must be realized in a specific environment that is according to the researchers the real environment of a secondary school. J.A. Whitcomb (2004) and J.J. Loughran (2006) consider the real environment to be extremely important and irreplaceable by any other form of preparation. The competence model also includes competencies that cannot be acquired and developed in a different way than in a real authentic environment. For example, application of didactic method, communication skills, creation of own professional image, management of teaching activities, self-regulation, etc.

Training as a creative activity determines the character of the students' preparation, allows them to clarify the main approaches to teaching, to gain experience of personal relation to the profession. The role of a teacher training is part of preparing prospective teachers for a future profession. From this point of view, its position in the study programmes as well as its position from the social aspect should be 
appropriate and should create a substantial part of the study programme. The situation about pedagogical training, which professionally prepares the prospective teacher to solve everyday situations in school practice, is different, worse. The situation differs from faculty to faculty, although in many faculties there is an attempt to make organizing pedagogical training professional. The fact that there is no minimum number of hours, terms, i.e. the length of training is determined by the criteria for each study period, causes the differences in preparing prospective teachers. It is important to admit that it is questionable worldwide what form, content, types of pedagogical training should be implemented as so-called "optimal". The researchers cannot say with a certainty what organizational, content, methodological and other qualities the training of students should have to fulfil all profile goals in the preparation of prospective teachers, i.e. there are no standards whereby passing of pedagogical training would be considered.

At present, universities that provide teacher training programmes determine the conditions of pedagogical training themselves. This has a relatively negative impact on teachers who are not, as some surveys show, sufficiently prepared to deal with difficult situations and pedagogical problems that teachers have to deal with at school (Kriz, 2014).

The researchers agree with the opinion (Gadusova, 2007) that the key factors influencing the success of the practical training of the students is the balance of the partner's understanding of four actors: general methodologist, field methodologist, prospective teachers' trainer and prospective teacher; the quality of communication between the participants in the process of professional teaching training and consistent leadership of students in the process of developing teaching competencies. It comes out that the practical training of students in the process of professional teachers' training requires a close connection at several levels:

- at the level of didactic method of teaching and field didactic method - cooperation of teachers of both disciplines at a specific faculty (especially the content and methodological connection of these disciplines),

- at the level of training methodologists of subjects and teacher trainers - coordinated leadership of the prospective teachers during their pedagogical training,

- at the level of the prospective teacher - teacher trainer, student - field methodologist interconnection of the theoretical and practical preparation of the student (prospective teacher) in the process of professional pedagogical training.

The meaning of pedagogical training according to B. Kosova (2002) is fulfilled when the methodologists of the faculty as well as the teacher trainers lead the student (prospective teacher) to develop:

- communicating with all participants in the pedagogical process in gaining experience in clear, understandable way of communication with the individual and the group, making positive interpersonal relationships,

- diagnostic capabilities to recognize the individual peculiarities of their students and their specific educational needs, the students' social relationships in the classroom, to feel the problems of the students and to understand them,

- psychodidactic competences based on the didactic transformation of the subject in the view of the peculiarities of students, the ability to effectively help children in learning, the ability to use appropriate strategies and methods for their meaningful learning,

- managerial competencies consisting of quality planning of students' learning process and the creation of learning programmes and tasks, good organizing of independent and cooperative learning of students,

- the ability to self-reflect their professional skills and personal qualities, etc.

In case of model prospective teachers' performances, both the prospective teacher and the teacher from the school evaluate the performance, i.e., whether it was good or not. It should be noted that when doing the evaluation of the performance it is often not about the analysis of the performance and experience of the teacher, but that the analysis is based only on a descriptive assessment of their work, which can hardly help improve the work of other teachers. Therefore, in order to analyse the performance well, it is necessary for the prospective teachers to identify in particular what didactic principle they want to demonstrate in their performance why there is a causal link between the methods and the results of their work, what mode of realization is the best based on the experience in their working conditions, and what 
they see is the contribution of the effort to the educational role. In this case, the teacher from the school does not deal with unnecessary details of the lesson, but evaluates the basic methodological idea of the lesson and the essence of the experience used. This is more important for improving than evaluating the training itself without mentioning a theoretical background, as prospective teachers can critically evaluate whether and how the experience gained could be used in working conditions.

\section{Pedagogical Training of Prospective Teachers at the University of Economics in Prague}

As mentioned above, the practical part of the academic preparation for the teaching profession is the practical training that is determined by the level of pedagogical training. Its importance in the preparation of prospective teachers cannot be questioned.

In the master's degree programme Teaching of Economic Subjects pedagogical training is implemented in two separate subjects: Didactics of Economics with pedagogical training and Didactics of Accounting with pedagogical training. The subjects are included in the study plan in the 2 nd year in the summer term. Their time allocation is $2 / 2$. Lectures and part of the seminars take place at the faculty, part of the seminars is implemented in the form of pedagogical training at faculty schools. The Department of Economic Teaching Methodology has a total of 9 faculty training schools. Students (prospective teachers) have a total of 10 performances during the pedagogical training, 5 in the subject Economics and 5 in the subject Accounting. Preparations for the lesson and the performances themselves are evaluated by the assigned teacher trainers. At least one performance (from each subject) is attended by the methodologist or a teacher from the Department of Economic Teaching Methodology. The assessment of the teacher trainer consists of a maximum of 6 points for the performance. Assessment and comments on the performance are recorded by the teacher trainers in the evaluation sheets that are available before the pedagogical training begins. The final assessment is done by the methodologist/ a teacher from the Department of Economic Teaching Methodology and the assessment is passed on the teacher of subject of didactics of economics with pedagogical training and the methodologist of accounting with pedagogical training. The assessment of the pedagogical training is included in the overall assessment of the subject. As an important part of pedagogical training considered by the researchers is self-evaluation of the student. In terms of improving the student's work, self-reflection is very important. If the researchers are to prepare a reflexive professional, it is important to develop a reflexive competence during the training.

\section{Methodology}

In this area quantitative and qualitative research was carried out. Respondents from the research were teacher trainers from faculty training schools and students of master's degree of Teaching of Economic Subjects at the University of Economics in Prague.

\section{A) Qualitative research}

Aim: Identify the weaknesses of performances attended by prospective teachers.

Respondents of research: 32 teachers of economic subjects who provide pedagogical training at faculty training schools.

Research method: interview (guided discussion).

\section{The main results of interview:}

Teacher trainers agree that the most problematic areas for prospective teachers are the following ones:

- managing the discipline in the classroom,

- the ability to motivate - to excite the students about the curriculum,

- inadequate estimation of the adequacy of lecturing,

- the first performances are similar to seminars at universities,

- speed of lecturing,

- $\quad$ an effort to say as much as possible (breaking of the "less is more" principle),

- problems with classroom management (style of leadership and organization of students' activities),

- problems with the writing structure on the board, 
- not keeping the required performance structure (absence of the final phase in the form of a summary and verification of the understanding of new curricula), and so on.

These findings correspond to the analysis of international pedagogical research databases by S. Veenman (Veenman, 1984; Prucha, 2013), with the most frequent problems of professional start-up of prospective teachers. The results of the analysis are shown in Table 1.

Table 1

Problems of the professional start-up of teachers

\begin{tabular}{|l|l|c|}
\hline Order & Problem & Frequency of occurrence \\
\hline 1. & Manage the discipline in the classroom & 85 \\
\hline 2. & Motivate students & 50 \\
\hline 3. & Adapt to the individual peculiarities of the students & 46 \\
\hline 4. & Evaluate students' results & 38 \\
\hline 5. & Develop relations with parents & 36 \\
\hline 6. & Inappropriate tools and materials & 32 \\
\hline 7. & Organize the student's work in the classroom & 30 \\
\hline 8. & Solving the problem of individual students & 30 \\
\hline 9. & The burden of teaching is too heavy & 29 \\
\hline 10. & Relations with colleagues & 27 \\
\hline The least frequent problems of the professional start of teachers & \\
\hline 22. & Lack of free time & 11 \\
\hline 23. & Insufficient help when starting teaching career & 10 \\
\hline 24. & Too many students in classes & 9 \\
\hline
\end{tabular}

Source: Problems of the professional start-up of teachers (Veenman, 1984; Prucha, 2013)

$\mathrm{F}$ is the frequency of occurrence of the "problem" in the total number of research analyses $(\mathrm{N}=100$, so $\mathrm{F}$ indicates the occurrence in percent of $\mathrm{N}$ ).

It is clear from the above analysis that it is advisable to continuously analyse the course of pedagogical training, to focus on assessment of pedagogical training by trainees and subsequently to try to eliminate the most frequent pedagogical problems of trainees through complex preparation within the subject which is a seminar on pedagogical training that precedes the pedagogical training itself. In the seminar, the methodologists should focus primarily on solving case studies focused on possible pedagogical, psychological and didactic problems that trainees can encounter during the pedagogical training itself.

\section{Recommendations}

The results of the discussion were taken as a consensus of the views and educational needs of all the parts involved, and were projected together with further experience from the whole course of the research into the following main conclusions and recommendations:

- obligatory students' observations - to use them as obligatory before starting their own pedagogical performances; previously the observations were only recommended to students, some students used that option, some not, which had a subsequent negative reflection on the level of their performances in the classroom at the faculty training schools,

- in the field of preparation of prospective teachers to strengthen the teaching of school legislation and management of education; there appeared opinions on the existence of separate subjects in which the subject matter would be taught or strengthened the relevant thematic units within the subject Pedagogy,

- to consider the creation of a separate subject Controlled Pedagogical Training (continuous for 2 weeks),

- to implement periodic seminars for teacher trainers and headmasters of faculty training schools so that mutual awareness, a proven exchange platform and sharing of opinions and experience are sustainable, 
- to require conducing of a pedagogical diary from the prospective teachers and documenting their systematic preparation during the whole time of pedagogical training,

- within seminars on the subjects of Didactics of Economics with pedagogical training and Didactics of Accounting with pedagogical training to include examples of good practice, e.g. videos of the performances of experienced teachers and prospective teachers of previous years and their comprehensive analysis.

\section{B) Quantitative research}

Aim: Identify the quality of pedagogical training.

\section{Research Hypotheses:}

H1: The researchers assume that students will evaluate the quality of organizing the pedagogical training positively.

H2: The researchers assume that students will positively evaluate the quality of methodical materials prepared by the methodologists of the Department of Economic Teaching Methodology (DETM).

H3: The researchers assume that the overall assessment of the quality of pedagogical training will be assessed by students on the scale 1 to 5 at least at level 3 .

Research Respondents: 47 students of the master' study programme Teaching of Economic Subjects at the University of Economics in Prague.

Research Method: questionnaire survey.

\section{The main results of questionnaire survey:}

The students had a scale of 1 - excellent, very good, very satisfied; 2 - very good, I like it, I'm happy; 3 good, sometimes I like it, sometimes I do not like it; 4 - weak, I do not like it, I'm dissatisfied; 5 - insufficient, I do not like it at all, I am very dissatisfied; 0 - I do not know how to express, I do not know how to judge; to evaluate the quality of selected areas of pedagogical training. The results are presented in Table 2.

Table 2

Assessment of Pedagogical Training

\begin{tabular}{|l|c|}
\hline Area of evaluation of pedagogical training & Average value \\
\hline Organization of pedagogical training & 1.68 \\
\hline Level of methodical materials & 1.95 \\
\hline Cooperation with a teacher trainer & 1.40 \\
\hline Cooperation with the methodologist from DETM & 1.33 \\
\hline Social climate at the training school & 1.74 \\
\hline Material equipment at a training school & 2.51 \\
\hline Time range of pedagogical training & 2.06 \\
\hline Assessment of students in pedagogical training & 1.76 \\
\hline Overall evaluation of pedagogical training & $\mathbf{1 . 8 0}$ \\
\hline
\end{tabular}

Source: Own research

\section{Discussion}

From the results presented in Table 1, Figure 1 and Figure 2 it is clear that students of the master's study programme Teaching of Economic Subjects evaluated the course of pedagogical training positively (1.80), the material equipment of training schools was considered as a weakness (2.51) - specifically equipment with projection technology, interactive whiteboards, multimedia learning aids, and so on. Another weak aspect is the time range of the pedagogical training (2.06) - students are forced to harmonize the performances at a training school with their study schedule at the university, which can cause problems. Students recommended existing training schools and teacher trainers for the pedagogical training. Based on the results obtained, the researchers can state that the hypotheses of $\mathrm{H} 1$, $\mathrm{H} 2$ and $\mathrm{H} 3$ have been confirmed. 


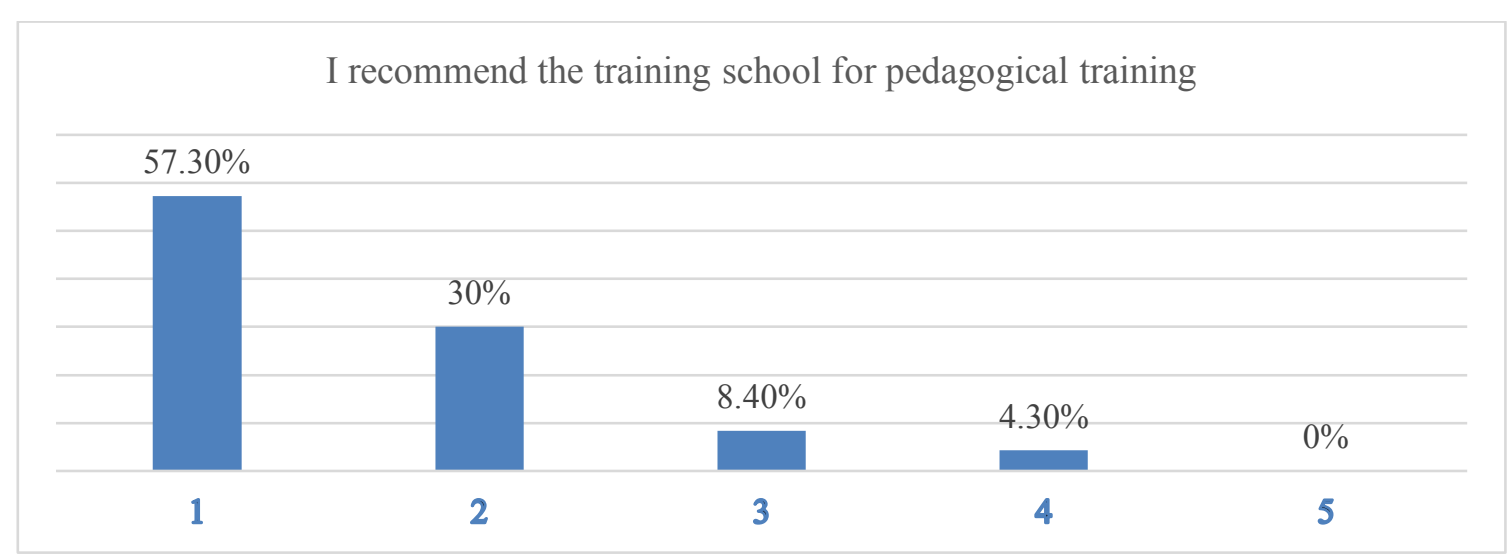

Figure 1. Students' Opinion on the Training School

There are opinions that students/prospective teachers at universities and colleges should acquire theoretical knowledge from the profile and related fields as part of their study, and practical experience should be acquired only in real life after leaving the school (Sykes, Bird, Kennedy, 2010).

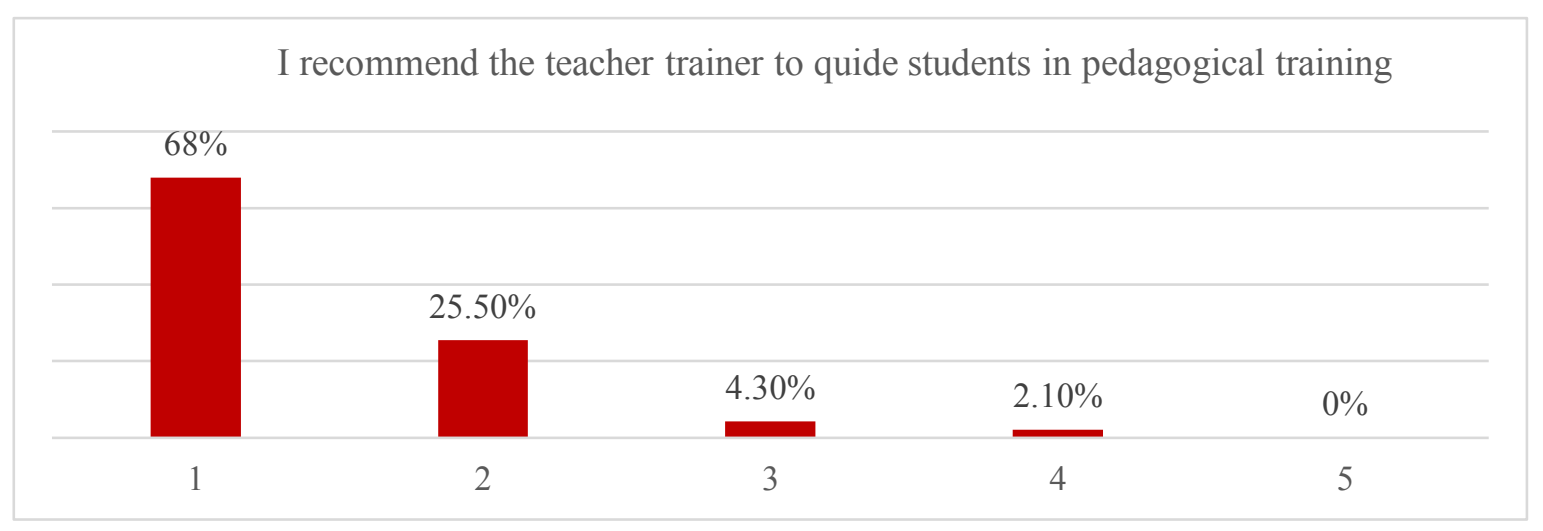

Figure 2. Students' Opinion on the Teacher Trainer

Likert scale: 1 - definitely yes; 2 - rather yes; 3 - I cannot judge; 4 - rather not; 5 - definitely not

Many American schools focusing on the training of prospective teachers underwent a successful transformation that had focused on standards, curriculum innovation and creating of stronger training. The greatest progress was recorded in the field of training, i. e. linking of theory and practice. The teacher certification system focused on verbal skills, knowledge content and lowered emphasis on teaching skills, with considering the weak contact with schools where teachers would work in the future as a weakness. Teachers require training in teaching and professional skills to be professionally prepared for their work. L. Darling-Hammond (2010) emphasizes that linking theory and practice is not possible without the active participation and collaboration of the university and the type of school which prospective teachers are prepared for. During their studies or pedagogical training, they can solve different educational problems, communicate with parents, school partners, come into contact with various student stereotypes, etc. The Scandinavian countries (Finland, Sweden, Norway and the Netherlands) have 1 year of pedagogical training in partner schools as part of their pedagogical training. On the other hand, the author points to the advanced Singapore system, where teacher education is provided by The National Institute of Education. Studies focus primarily on the development of key competencies for the 21 st century i.e. they develop critical thinking, skills in curriculum, technology and economics. The government supports and puts great emphasis on the professional help of the teaching staff. G. Sykes, T. Bird and M. Kennedy (2010) see the disparity between general university education and practice. This phenomenon causes insufficient preparation of "novices", i.e., starting teachers. According to them, novice teachers should have the knowledge of the field, they should be competent and want to be constantly educated and the initial training should be acquired at the appropriate school. The authors highlight the possibilities of cooperation between universities and schools in the field of early-stage teachers.

Ball D.L. and Forzani F.M. (2009) admit the difficulty of including real pedagogical training in the US prospective teachers study programmes, but they see the possibility of creating a practice-focused curriculum. 


\section{Conclusions}

Under the influence of constantly changing pedagogical training, the variety of pedagogical situations that may arise during the course of teaching and innovation in economic fields, the process of increasing teachers' pedagogical competencies is being permanent. Pedagogical training is an inseparable part of the comprehensive preparation of students in the teaching profession. The content of pedagogical training integrates all the components of university education of the prospective teachers - engineers. It provides students with the opportunity to verify the acquired theoretical pedagogical-psychological as well as professional subject knowledge in practice and to acquire the basic practical skills necessary for the performance of the teaching profession. The results of qualitative research have shown that the most common problems for the prospective teachers when teaching were to manage class discipline, to have the ability to motivate students, and the lack of adequacy of the topic when lecturing. The results of quantitative research have shown that the course of pedagogical training was evaluated by students positively but the material equipment of training schools and the time range of pedagogical training were assessed as a weaker side. The researchers are inclined to believe that it is appropriate to include different forms of training in the preparation of prospective teachers, bringing together theory and practice, but it is important to remember that no simulations will replace the direct experience in real practice, i.e. in training schools. This view is supported by long-term experience not only in their country but also abroad.

The paper was written with the support of project VŠE IGS F1/7/2018 and it is one of the outputs of the research project of the Faculty of Finance and Accounting of the University of Economics, Prague carried out with help of institutional support of VŠE (Project VŠE No. IP 100040).

\section{Bibliography}

1. Ball D.L., Forzani F.M. (2009). The Work of Teaching and the Challenge for Teacher Education. Journal of Teacher Education. 60 (5), 497 - 511. American Association of Colleges for Teacher Education. Retrieved from https://doi.org/10.1177/0022487109348479

2. Darling-Hammond L. (2010). Teachers Education and the American Future. Journal of Teacher Education. 61 (1-2), 35 - 47. American Association of Colleges for Teacher Education. Retrieved from https://doi.org/10.1177/0022487109348024

3. Gadusova Z. (2007). Rozvoj reflexie a sebareflexie v ramci pedagogickej praxe (Development of reflection and self-reflection within pedagogical training). In Pedagogicka prax - sucasnost' a perspektívy. Nitra: FF UKF. (in Slovak)

4. Kosova B. (2002). Idea spoluprace univerzity a cvicnych skol. In B. Kasacova (Ed.), Spolupraca univerzity a skol. "Cvicny ucitel". (Collaboration of the University and Schools. "Teacher Trainer"), 18(1). Banská Bystrica: PF UMB, 10 - 13. (in Slovak)

5. Kozina F.R., Erjavsek M., Kostanjevec S. (2015). Student Teachers' Perception of Teaching Competences' Development through Teaching Practice. In V. Dislere (Ed.), The Proceedings of the International Scientific Conference Rural Environment. Education. Personality (REEP), 8. Jelgava: LLU TF, 109-114. Retrieved from http://lufb.llu.lv/conference/REEP/2015/Latvia-Univ-AgricultREEP-2015proceedings.pdf

6. Kriz E. (2014). Training teacher at pedagogical practice of students - the partner of academic teacher. In V. Dislere (Ed.), The Proceedings of the International Scientific Conference Rural Environment. Education. Personality (REEP), 7. Jelgava: LLU TF, 187-191. Retrieved from http://lufb.llu.lv/conference/REEP/2014/Latvia-Univ-Agricult-REEP-2014proceedings.pdf

7. Loughran J.J. (2006). Developing a pedagogy of teacher education. London: Routledge.

8. Prucha J. (2013). Moderní pedagogika (Modern Pedagogy). (5th ed.) Praha: Portál. 211 - 213. (in Czech)

9. Sykes G., Bird T., Kennedy M. (2010). Teacher Education: Its Problems and Some Prospects. Journal of Teacher Education. American Association of Colleges for Teacher Education. 61 (5), 464 - 476.

10. Veenman S. (1984). Perceived Problems of Beginning Teachers. Review of Educational Research Summer, 54(2), 143-178. Retrieved from

http://citeseerx.ist.psu.edu/viewdoc/download?doi=10.1.1.834.9292\&rep=rep1\&type=pdf

11. Whitcomb J.A. (2003). Practice matters: Reflections on the importance of the educator's practice. In D. McInerney, S. VanEtten (Eds.) Sociocultural Influences and Teacher Education Programs. Greenwich, CT: Information Age Publishing, 15 - 33. 